\title{
PRODUCTION OF VOLATILE ORGANIC COMPOUNDS (VOCS) BY TEMPERATE MACROALGAE. THE USE OF SOLID PHASE MICROEXTRACTION (SPME) COUPLED TO GC-MS AS METHOD OF ANALYSIS
}

\author{
C. M. BRAVO-LINARES ${ }^{\prime *}$, S. M. MUDGE ${ }^{2}$ and R. H. LOYOLA-SEPULVEDA ${ }^{3}$ \\ ${ }^{1}$ Universidad Austral de Chile, Facultad de Ciencias, Instituto de Química. P.O. Box 567. Valdivia, Chile. \\ ${ }^{2}$ School of Ocean Sciences, Bangor University, Menai Bridge, Anglesey LL59 5AB, UK. \\ ${ }^{3}$ Universidad Católica de la Santísima Concepción, Facultad de Ciencias, Alonso de Ribera 2850 Concepción, Chile. \\ (Received: July 23, 2009 - Accepted: January 27, 2010)
}

\begin{abstract}
Volatile organic compounds (VOCs) are produced by macroalgae in response to environmental stresses. A novel approach using Solid Phase Microextraction (SPME) was used to quantify the production of several VOCs from eight common intertidal algal species from the UK (Ascophyllum nodosum (Linnaeus) Le Jolis, Fucus vesiculosus (Linnaeus), Fucus serratus (Linnaeus), Laminaria digitata (Hudson) Lamouroux, Ulva lactuca (Linnaeus), Ulva intestinalis (Linnaeus), formerly known as Enteromorpha, Palmaria palmata (Linnaeus) Kuntze and Griffithsia flosculosa (J. Ellis) Batters). The volatile compounds included halogenated, sulphur containing, aldehydes, non-methane hydrocarbons (NMHC) and oxygenated species. Overall, the production of VOCs by these algae was not considerably different under illumination or in darkness; this suggests that the VOC production occurs during both algae photosynthesis and in other metabolic processes such as respiration or osmoregulation. Desiccation played an important role in the production of VOCs with greater production by macroalgae after desiccation. This production was related to the alga's normal position within the intertidal zone; there was a lower production of VOCs for species growing near the high water mark and a greater production for algae taken from the low tide position. There were also species differences in the VOC profiles and quantities released. For example, chlorinated and oxygenated compounds were principally released by the brown alga Ascophyllum nodosum, while green algae such as Ulva lactuca and Ulva intestinalis released greater amounts of brominated, sulphur containing compounds, aldehydes and non-methane hydrocarbons than the other algae tested. The kelps (e.g. Laminaria digitata) had the greatest release of iodinated compounds such as diiodomethane. These processes make significant contributions to the VOCs in seawater and, by transfer to the atmosphere, in the coastal atmosphere.
\end{abstract}

Keywords: VHOCs (volatile halogenated organic compounds), desiccation, exposure, fluxes, seaweeds, Solid Phase Microextraction (SPME), oxygenated and sulphur-containing volatile organic compounds.

\section{INTRODUCTION}

Marine biota produce a great variety of volatile organic compounds (VOCs) and these compounds are of diverse biosynthetic origins ${ }^{1}$. Halogenated compounds may be produced by a range of marine organisms including marine bacteria, algae and several classes of marine invertebrates ${ }^{2}$. These organisms excrete many organic compounds directly into the sea water as a mechanism for removal of metabolic wastes and as chemical communicants ${ }^{3}$, for chemical protection ${ }^{4}$, as secondary waste compounds formed with the help of peroxidases to lower the high concentration of hydrogen peroxide formed in algal cells ${ }^{5}$, in response to oxidative stress ${ }^{6}$, for anti-herbivory activity ${ }^{7}$, antimicrobial action ${ }^{8}$ to facilitate food gathering or as hormones ${ }^{2}$ and other reasons not yet clearly understood.

The production of halocarbons and other VOCs by marine algae may be more important on a local scale due to the occurrence of high biomass in coastal regions ${ }^{9,10}$. On the other hand, other authors propose that marine algae may be a significant source of VOCs to both the total local and global environments 11,12 . However, this consideration depends on the types of compounds considered. Macroalgae produce around $70 \%$ of the world's bromoform ${ }^{11}$ and combined emissions of macro and microalgae contribute substantial amounts of bromine to the global cycle, perhaps in the same order of magnitude as anthropogenic sources ${ }^{13}$. Marine macroalgae may also be the major source of the polybromomethanes in marine environments ${ }^{11}$. Brominated and iodinated volatile halocarbons are principally produced from natural sources but chlorinated compounds have mixed sources such as biota and industrial processes ${ }^{14}$, The physiological mechanisms for VOC production are still not well understood but, the formation of halocarbons by haloperoxidases enzymes 16 through the oxidation of halogens in the presence of hydrogen peroxide, is considered important. Several authors have found enzymatic activity in algae including bromoperoxidases ${ }^{17}$, chloroperoxidases ${ }^{18}$, iodoperoxidases ${ }^{19-21}$ and methyltransferases ${ }^{22}$. There is some evidence that the halocarbons are produced by other enzymatic mechanisms.

Another such pathway may be the reaction of hypobromous acid $(\mathrm{HBrO})$, an extremely reactive species, with organic matter to form volatile halocarbons. Hypobromous acid can be formed by haloperoxidases located near the macroalgal outer surface and then released directly into seawater; $\mathrm{HBrO}$ has been proposed as a strong biocide and the production of halocarbons by seaweed is considered part of a host defence system ${ }^{23}$.

External factors such as light availability and desiccation can play an important role on the VOC production. Results obtained with light exposure ${ }^{24}$ showed that light and dark periods had no influence on the release of volatile halocarbons. However, several authors ${ }^{13,25}$ have found an increase in the production of halocarbons under illumination due to algal photosynthetic activity ${ }^{26}$. Laboratory experiments suggested that release rates can be affected by partial desiccation, light availability, tissue age, tissue wounding and grazing ${ }^{27}$.

The presence of VOCs in the atmosphere is of considerable importance as they may directly affect human health ${ }^{28}$, lead to the formation of cloud condensation nuclei ${ }^{29}$ and affect the climate at both the local and global scales 30.

As part of a wider investigation into VOCs in the coastal marine environment ${ }^{31,32}$, a study was undertaken to determine the contribution that macroalgae make to VOCs in local seawater for subsequent transfer to the atmosphere. These studies were undertaken using Solid Phase MicroExtraction (SPME) techniques which have been shown to have a wider applicability and greater sensitivity for biogenic VOCs than other methods ${ }^{33}$.

\section{MATERIALS AND METHODS}

\section{Sample site and collection}

Different species of fresh brown [Phaeophyta: Ascophyllum nodosum, Fucus vesiculosus (FV), Fucus serratus (FS), Laminaria digitata (LD)], red [Rhodophyta: Palmaria palmata (PP) and Griffithsia flosculosa (GF)] and green macroalgae [Chlorophyta: Ulva lactuca (UL), Ulva intestinalis (EN)] were collected from the field on different days at low tide from the Menai Strait (Latitude $53^{\circ} 13.521 \mathrm{~N}$, Longitude $04^{\circ} 09.549 \mathrm{~W}$ ), North Wales. These algae chosen were the most abundant in the Strait and are common to shores around the UK and Northern Europe. Figure 1 shows schematically where the algae were collected from according to their position in the intertidal zone. 


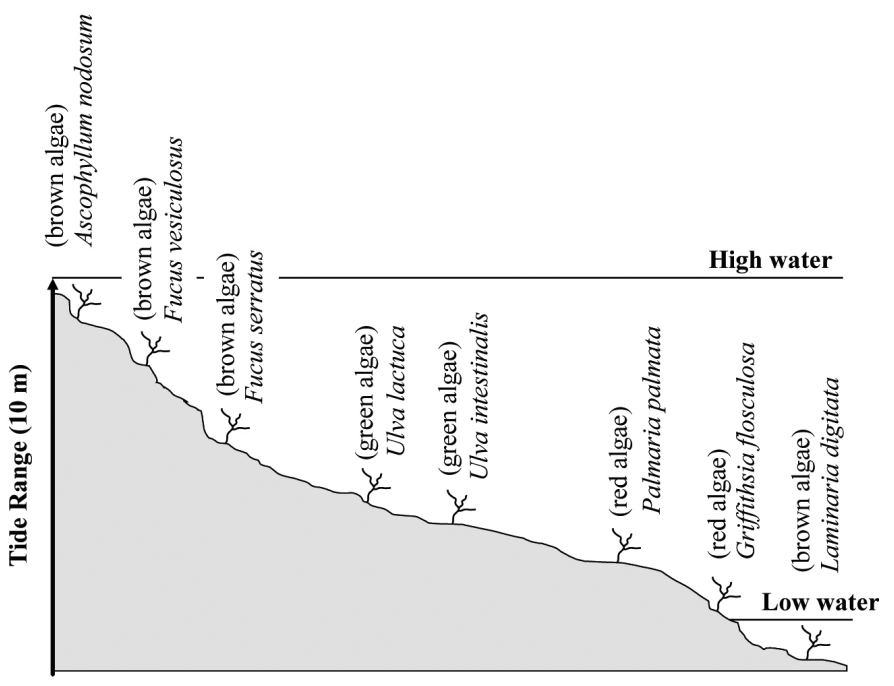

Fig. 1. Intertidal profile showing the relative position of the macroalgae collected for the experiments (tidal range $10 \mathrm{~m}$ ).

\section{Illumination conditions}

As a source of photosynthetic active radiation (PAR), a set of Sylvania Grolux ${ }^{\circledR}$ F20W/GRO (Germany) lamps were employed. A Biospherical Instruments Inc. QS2-100 irradiance meter was used to measure photon irradiance. The values were measured by placing the sensor $10 \mathrm{~cm}$ from the lamps $(50 \mathrm{mmol} \mathrm{m}-2 \mathrm{~s}-1)$ and inside the bottles with seawater $\left(68 \mathrm{mmol} \mathrm{m}^{-2} \mathrm{~s}^{-1}\right)$.

\section{Temporal Evolution of VOCs}

Prior to collection of the algae, a series of glass bottles filled with $4.5 \mathrm{~L}$ of filtered seawater (sand filter, $30 \mathrm{~mm}, 10 \mathrm{~mm}, 5 \mathrm{~mm}, 0.2 \mathrm{~mm}$ and irradiated with a UV lamp) were left overnight (6-8 hours) bubbling with filtered air to saturate the water with oxygen. The algae were collected early in the morning from the intertidal zone. They were transported immediately in seawater to the laboratory and washed with filtered seawater to remove adhering particles. Grazers and other marine organisms on the algae were removed by hand and only visibly undamaged algae were selected for the experiments. Algae were weighed to use roughly the same amount $(300 \mathrm{~g})$ for each experiment and placed in the seawater-filled bottles under illumination for 3, 6, 9, 12 hours and sealed with rubber stoppers covered with a thick film of Teflon, leaving no head space. Another experiment was run in parallel under dark conditions for 12 hours. The algae were placed in the bottle, covered with aluminium foil and incubated in a box at the same temperature as the test algae. Two blanks per experiment were also run; one with seawater at the start and the other after 12 hours exposure to the light source but without algae. This was to determine the photochemical production of VOCs in the seawater despite the filtration and sterilisation process.

The temperature of the seawater was measured before and after the incubation and it varied between 16 and $20^{\circ} \mathrm{C}$. The temperature did not increase by more than 2 degrees throughout the experiments. Water content of the algae was determined after the experimental period by drying at $50^{\circ} \mathrm{C}$ for two days.

\section{Desiccation induced VOC production}

To determine which VOCs are produced by algae at low tide when they are exposed to the atmosphere and subsequently re-hydrated, the following experiment was performed. The same procedure of collecting and pre-treating the algae described above was followed. Only algae which are normally exposed to desiccation at low tides were used although the red algae were also excluded. One species was collected per day. After cleaning, the algae were hung at room temperature $\left(16\right.$ to $\left.18^{\circ} \mathrm{C}\right)$ for up to six hours. The first sample was not exposed to desiccation; it was immediately placed into filtered seawater as above and the VOC content analyzed one hour later. The other samples were exposed to the air for 2, 4 and 6 hours before placing in seawater for one hour. A blank with treated seawater was run in parallel to determine the abiotic production of VOCs in the water prior to the start of the experiment.

\section{VOC analysis}

After the incubation process the algae were quickly removed from the bottles with a metal hook (minimal losses of the volatile fraction were assumed during this process as the system was not being purging and there was no head space in the bottle). The bottles were spiked with the internal standard (4-bromofluorobenzene $2 \mathrm{ng} \mathrm{L}^{-1}$, Supelco) and purged with extra pure nitrogen $\left(\sim 150 \mathrm{~mL} \mathrm{~min}^{-1}\right)$ for 1 hour at ambient temperature with continual stirring to homogenize the sample and release the VOCs dissolved in the seawater. The nitrogen passing through the seawater was previously purified across an organic trap (ELGA) to minimize the possible volatile organic content in this gas.

The VOCs released during the purging process were trapped on a SPME fibre ( $2 \mathrm{~cm}-50 / 30 \mathrm{~mm}$ DVB/carboxen/PDMS from Supelco). The fibre was preconditioned for 1 hour at $230^{\circ} \mathrm{C}$ in a split/splitless port (split open) with helium as a carrier gas before each extraction procedure. The compounds adsorbed on the fibre were immediately desorbed for 5 minutes at $230^{\circ} \mathrm{C}$ with the split/ splitless valve closed. A Jade valve kit for SPME for Fisons series 8000 from Alltech was used as an injector device for the fibre's syringe. The same fibre was used throughout the experiments.

The VOC content of the extracted samples were analyzed on a Fisons MD 800 Gas Chromatograph coupled to a mass spectrometry detector (GC-MS). A fused silica capillary column AT-502.2 (Alltech $60 \mathrm{~m}$ x0.32 mm i.d. and film thickness $1.8 \mathrm{~mm}$ ) was used for the separation of all halocarbons and other VOCs. The chromatographic conditions were: helium as a carrier gas $(\sim 4.3 \mathrm{~mL}$ min-1), at a pressure of $140 \mathrm{Kpa}$; temperature programme: $40^{\circ} \mathrm{C}$ held for $5 \mathrm{~min}$, $4^{\circ} \mathrm{C}$ min- 1 to $60^{\circ} \mathrm{C}$ held for 3 minutes, $4^{\circ} \mathrm{C}$ min- 1 to $80^{\circ} \mathrm{C}$ and held for $2 \mathrm{~min}, 4^{\circ} \mathrm{C}$ $\mathrm{min}^{-1}$ to $150^{\circ} \mathrm{C}$ and isothermal at $150^{\circ} \mathrm{C}$ for $10 \mathrm{~min}$. Injector temperature was kept in $230^{\circ} \mathrm{C}$. The mass spectra conditions were: electron impact ionisation $(70 \mathrm{eV})$, source temperature at $200^{\circ} \mathrm{C}$ and interface temperature at $160^{\circ} \mathrm{C}$.

Initial identification of VOCs was performed in scan mode $(47-270 \mathrm{~m} / \mathrm{z})$. Quantification was done using the internal standard and calibration curves of halocarbons standard (JMHW VOC Mix A, 16 analytes $1000 \mathrm{mg} \mathrm{mL}^{-1}$, Supelco) as well another 15 pure compounds (halogenated, oxygenated, aldehydes, NHMCs and DMS) obtained from a range of suppliers to supplement the initial JMHW standard. Single ion monitoring (SIM) was used to quantify the compounds of interest. The targets compounds were equally divided through two SIM programs and care was taken to have the same dwell time and interchannel delay among the fragments. Standards were purged, concentrated and analysed in the same way as VOCs produced by the investigated macroalgae.

In order to determine the optimum time of purging an experiment was developed by spiking treated seawater with VOCs standards whose final concentration was $100 \mathrm{ng} \mathrm{L}^{-1}$ and then purged for 30, 60, 90 and 120 minutes. Results showed that 1 hour was sufficient time to reach the equilibrium of adsorption on to the SPME fibre for the volume of seawater purged $(4.5 \mathrm{~L})$ for all the VOCs quantified ${ }^{34}$.

\section{RESULTS ANS DISCUSSION}

\section{Water content}

The water content of the algae was variable with maximal values in the red species. Table 1 shows the algae studied and their respective water content. In general, the red algae contained more water which was also lost more readily during drying than either the green or brown algae (data not shown).

Table 1. The water content of the algae investigated $(n=5)$ and the rate of water loss over the six hour desiccation period.

\begin{tabular}{|c|c|c|c|c|}
\hline & Algal type & $\begin{array}{l}\% \text { of } \\
\text { water }\end{array}$ & SD & $\begin{array}{c}\text { Rate of water } \\
\text { loss }\left(\% \cdot \mathbf{h}^{-1}\right)\end{array}$ \\
\hline \multirow{4}{*}{ 苟 } & $\begin{array}{l}\text { Ascophyllum } \\
\text { nodosum }\end{array}$ & 68.7 & 1.3 & 7.6 \\
\hline & Fucus vesiculosus & 76.7 & 0.6 & 7.4 \\
\hline & Fucus serratus & 79.2 & 1.6 & 6.4 \\
\hline & Laminaria digitata & 79.2 & 0.9 & 11.6 \\
\hline \multirow{2}{*}{$\begin{array}{l}\text { ठี } \\
\text { Ðँ }\end{array}$} & Ulva lactuca & 75.3 & 1.1 & 8.8 \\
\hline & Ulva intestinalis & 78.9 & 1.2 & 4.0 \\
\hline \multirow{2}{*}{$\stackrel{\ddot{\mathscr{U}}}{\simeq}$} & Palmaria palmata & 86.2 & 0.3 & - \\
\hline & Griffithsia flosculosa & 88.0 & 0.3 & - \\
\hline
\end{tabular}

-:not measured 


\section{Blank analysis}

Seawater used to incubate the macroalgae contained target VOCs at trace levels $\left(<40 \mathrm{pg} \mathrm{L}^{-1}\right)$ despite the pre-treatment (filtration and UV disinfection). However, these concentrations were orders of magnitude less that those obtained from the experiments and may be considered negligible. This presence was not unexpected as the seawater used was originally taken from the deeper layers in the Menai Strait which naturally contains these compounds. The blank concentrations were subtracted from those obtained for each experiment. In the illumination experiments, the initial blank concentrations were similar to those after 12 hours indicating no net production or degradation over this period. Therefore, the blank concentrations at 0 and 12 hours were averaged and then subtracted from the corresponding samples.

\section{Temporal evolution of VOCs}

Forty seven different VOCs were identified and quantified in the studied algae. These compounds had previously been detected in local seawater samples indicating that macroalgae are a potential source of many VOCs in the bulk seawater ${ }^{32}$. Not all algae produced all VOCs and some were specific to the type of algae and their general groups (brown, red or green). Figure 2 shows the production of selected VOCs throughout the incubation period under illumination and under dark conditions.

Bromoform (Figure 2) was detected in all the algae studied; it was produced in greater proportions by green algae compared to the other algae (up to 25 times more). This is in contrast to the findings of Laturnus, $2001{ }^{9}$ who found much greater daily bromoform fluxes in Desmarestia and several other phaeophytes and rhodophytes than in green algae. Production in darkness was considerably less than under illumination; production was also enhanced by longer incubation times which agrees with findings of Carpenter, et al, $2000^{35}$. Concentrations of bromoform for all the studied algae ranged from 0.4 to 42.2 $\mathrm{ng} \mathrm{g}^{-1} \mathrm{DW} \mathrm{h}^{-1}$, lower values than those reported by Nightingale, et al $1995^{27}$ of 0 to $1,250 \mathrm{ng} \mathrm{g}^{-1} \mathrm{DW} \mathrm{h}^{-1}$ with similar algae. Diiodomethane (Figure 2) behaved similarly to bromoform. Its concentration was greatest in the Laminaria samples with a mean value of $4.38 \mathrm{ng} \mathrm{g}^{-1} \mathrm{DW} \mathrm{h}^{-1} .{ }^{25}$ reported that diiodomethane was the main iodinated compound released by brown macroalgae. Tetrachloroethene (Figure 2) was only produced by brown macroalgae and production was similar under both dark and light conditions. Evidence of natural production of this compound by marine macroalgae were given by Abrahamsson, et al $1995^{14}$ who reported concentrations in the range of 0.003 to $8.2 \mathrm{ng} \mathrm{g}^{-1} \mathrm{FW} \mathrm{h}^{-1}$; these data are much lower between 0.001 and $0.006 \mathrm{ng} \mathrm{g}^{-1} \mathrm{FW} \mathrm{h}^{-1}$. However, it is important to consider that this finding has been disputed by other investigators who do not consider macroalgae to be a source of tetrachloroethene ${ }^{36,37}$.

Bromodichloromethane (Figure 2) also behaved similarly to bromoform, indicating a similar mechanism of formation. Production rates ranged from 0 to $0.68 \mathrm{ng} \mathrm{g}^{-1} \mathrm{DW} \mathrm{h}^{-1}$. Dimethylsulphide (DMS) and dimethyldisulphide (DMS $\left.{ }_{2}\right)$ concentrations tended to increase under illumination. However, a major release of both compounds was observed from the algae were kept in the dark for 12 h. Green algae had the highest production rate of the studied algae. Production of DMS for all the studied algae ranged from 0.005 to $7.61 \mathrm{ng} \mathrm{g}^{-1} \mathrm{DW} \mathrm{h}^{-1}$ under illumination and 0.019 to $13.36 \mathrm{ng} \mathrm{g}^{-1} \mathrm{DW} \mathrm{h}^{-1}$ under darkness, and for DMS of 0.001 to $8.92 \mathrm{ng} \mathrm{g}^{-1} \mathrm{DW} \mathrm{h}^{-1}$ and 0.001 to $27.36 \mathrm{ng} \mathrm{g}^{-1} \mathrm{DW} \mathrm{h}^{-1}$ respectively.

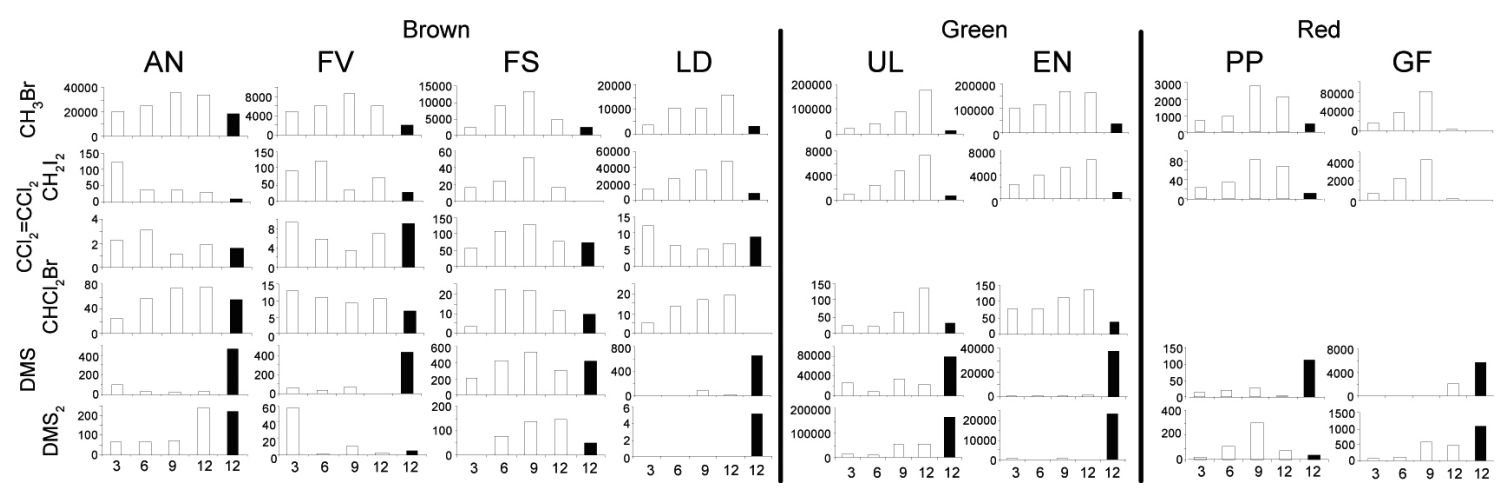

Fig. 2. Examples of some of the VOCs produced by algae in the Menai Strait ( $\mathrm{pg} \mathrm{g}^{-1} \mathrm{DW}$ ): a) bromoform, b) diiodomethane, c) tetrachloroethene, d) bromodichloromethane, e) DMS and f) $\mathrm{DMS}_{2}$. White bars represent the concentrations obtained at 3,6,9 and 12 hours of immersion for each alga. Dark bars represent the dark condition after 12 hours. AN: Ascophyllum nodosum, FV: Fucus vesiculosus, FS: Fucus serratus, LD: Laminaria digitata, UL: Ulva lactuca, EN: Enteromorpha sp, PP: Palmaria palmata and GF: Griffithsia flosculosa. Blank spaces mean that the compound was not detected for a particular type of algae. nd: not detected or below the limit of detection.

Figure 3 presents the total production of VOCs by group of chemicals and type of algae. The chlorinated compounds measured included 1,1-dichloroethene, dichloromethane, chloroform, 1,1,1-trichloroethane, trichloroethene, 1,1,2-trichloroethane, tetrachloroethene, 1-chlorobutane, 2-chlorobutane and 2-chloropropane which were produced in the greatest amounts by Ascophyllum nodosum (Figure 3a). Production under illumination was greater than under dark conditions. Mixed halogenated compounds (bromodichloromethane, dibromochloromethane and chloroiodomethane) and brominated (1-bromoethane, 1-bromopropane, 2,3-dibromopropene, dibromomethane, 1-bromopentane and bromoform) compounds are shown in Figure $3 \mathrm{~b}$ and $\mathrm{c}$. Bromoform was the main compound produced (up to 4,000 times more concentrated than other brominated compounds). Iodinated compounds shown in Figure 3d (iodoethane, 2-iodopropane, 1-iodobutane, diiodomethane and iodomethane) were produced in greatest quantities by Laminaria digitata as proposed by Kupper, et al. $2008{ }^{38}$. Laminariales are the strongest accumulators of iodine within living organisms and the major source of iodocarbons in the coastal atmosphere. Sulphur containing compounds $\left(\mathrm{DMS}\right.$ and $\mathrm{DMS}_{2}$ ) (Figure 3e) were produced in higher concentrations by green algae and this production was dominated by dark production rather than under illumination. The aldehydes detected included hexanal, heptanal, octanal and decanal (Figure 3f). Their production was enhanced by light conditions as well for other oxygenated compounds such as 2,4-dimethylfuran (Figure $3 \mathrm{~g}$ ) and might be in response to an oxidative burst. Non-methane hydrocarbons from $\mathrm{C}_{5}$ up to $\mathrm{C}_{11}$ (Figure $3 \mathrm{~h}$ ) were generated principally in dark conditions. Total production of VOCs per algae type (Figures $3 \mathrm{i}$ ) and the mean value per algae class (Figure $3 \mathrm{j}$ ) showed that the production of these compounds under illumination and darkness were not significantly different for green algae; similar findings were obtained by Collen, et al. $1994{ }^{35}$. However, brown and red algae produced more compounds under light conditions rather than in the dark 

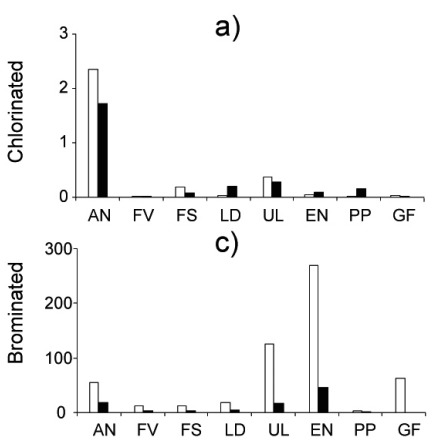

e)
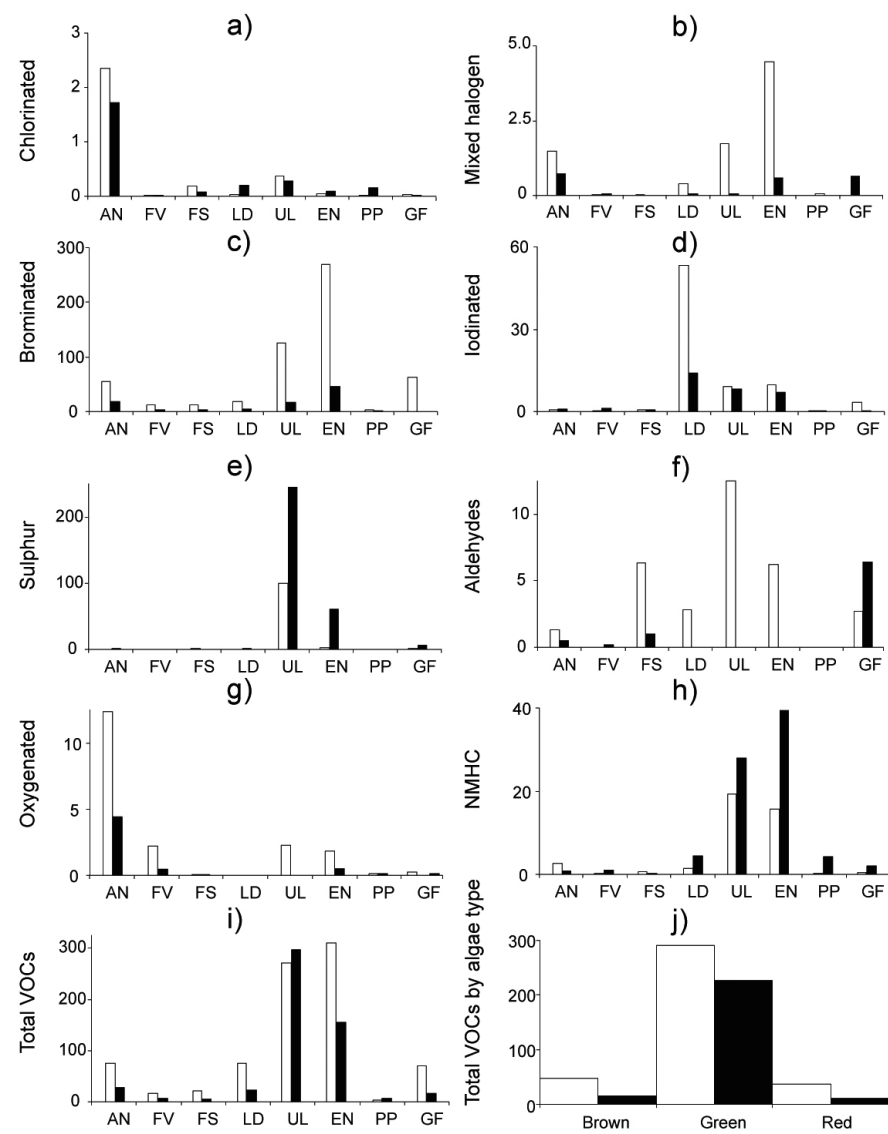

h)
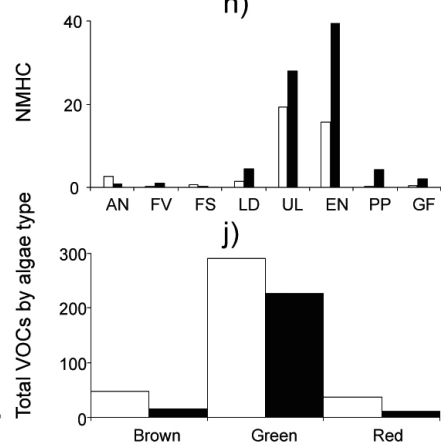

Fig. 3. Fluxes of different groups of VOCs $\left(\mathrm{ng} \mathrm{g}^{-1} \mathrm{DW} 12 \mathrm{~h}^{-1}\right)$ produced under illuminated (open bars) and dark (black bars) conditions.

\section{Desiccation induced VOC production}

Losses of water due to natural desiccation of algae were practically linear over the $6 \mathrm{~h}$ exposure period and the rate can be seen in Table 1. Desiccation was greater in algae normally found low in the intertidal zone, with values of $72 \%$ for Laminaria digitata and $52 \%$ for Ulva lactuca after 6 hours of desiccation. This may be due to the large surface area, which is favourable for water evaporation. Losses of water were intermediate for the other brown algae (38 to $48 \%$ ). Ulva instestinalis had the lowest value (28\%) as its form facilitates the retention of water for longer periods.

Results of the VOCs released after re-immersion are shown in Figure 4. The production of chlorinated and brominated compounds (Figures 4a and c) decreased after desiccation. The opposite was observed for mixed halogen and iodinated (Figures $4 \mathrm{~b}$ and d) compounds. Large amounts of iodinated VOCs were produced by Laminaria digitata. Sulphur containing VOC production (Figure 4e) decreased with increasing desiccation time. Ulva lactuca produced more of these compounds than the other algae. NMHC (Figure 4f) decreased for Ascophyllum nodosum, Fucus vesiculosus and Fucus serratus and increased for Ulva lactuca, Laminaria digitata and Ulva intestinalis.

The trends for aldehydes (Figure $4 \mathrm{~g}$ ) were not clear, except for Laminaria digitata whose production increased. In general VOCs (Figure $4 \mathrm{~h}$ ) tended to increase throughout desiccation.
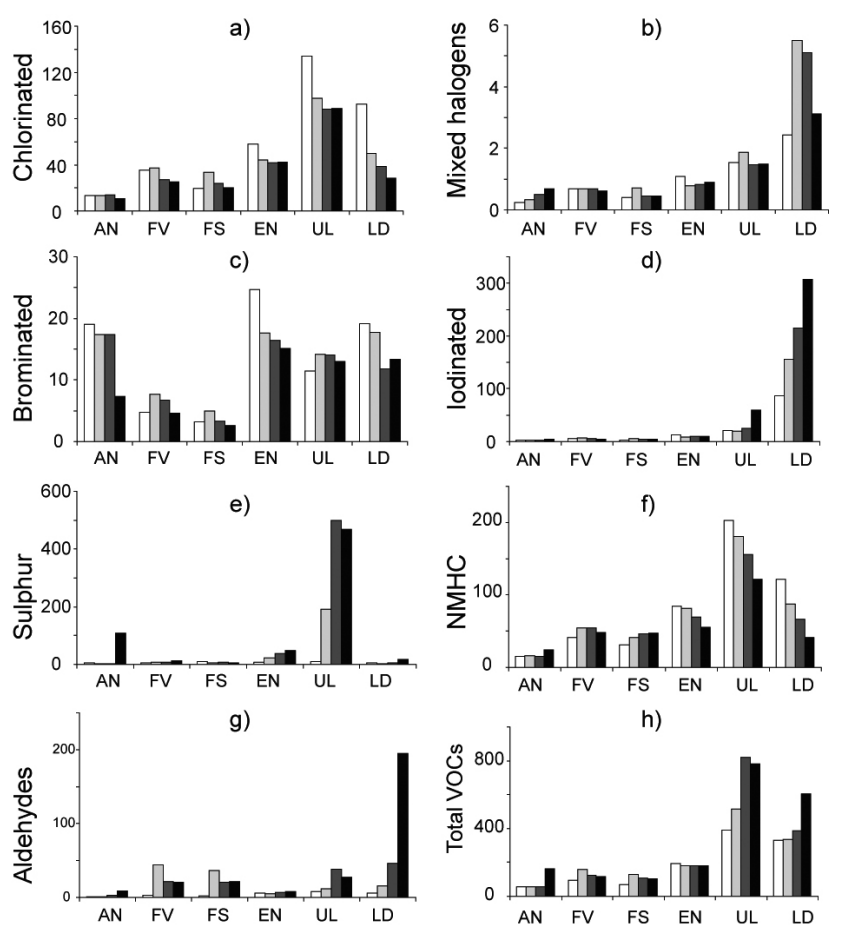

Fig. 4. Summary of all VOCs per type in $\mathrm{ng} \mathrm{g}^{-1} \mathrm{DW}$ after 0 (white bars), 2 (light grey bars), 4 (dark grey bars) and 6 (black bars) hours of desiccation. Where: a) Total chlorinated compounds, b) Total mixed halogens compounds, c) Total brominated compounds, d) Total iodinated compounds, e) Total sulphur containing compounds, f) Total NMHC compounds, g) Total aldehydes compounds and $h$ ) Total VOCs detected.

The studied macroalgae showed that under continuous immersion in seawater the production of VOCs was enhanced and this production was species dependent and promoted by light. It is possible to summarise and analyse the relationships between VOC, illumination and species through Principal Component Analysis (PCA). The dry weight flux data were converted to proportions to remove the concentration effect on the results and the compound loadings and scores plots are superimposed in Figure 5.

Production of halogenated compounds especially by Ascophyllum nodosum seems to be light dependent and related to photosynthesis ${ }^{39}$. Brominated compounds, particularly bromoform, have been reported as the main compound produced by marine macroalgae ${ }^{4,40}$. According to Klick, 1993 ${ }^{39}$ production of brominated compounds occurred mainly on exposure to the light, which was confirmed in this research. In Figure 5, bromoform was the key VOC in leading to the spatial positioning of Ascophyllum nodosum in the PCA scores plot. All illuminated samples and the dark samples were in the upper right quadrant indicating a VOC signature dominated by bromoform. Iodinated compounds were produced mainly by the brown alga Laminaria (LD in Figure 5 ) and this alga is considered an important source of iodinated compounds from the ocean to the atmosphere ${ }^{20,25}$. However, with regard to exposure of the Laminaria species which occur at the extreme low water position on the shore, there will be regional differences. These algae are only exposed to the air at low water on spring tides and the timing of this condition varies around the coast. For example, on Anglesey in North Wales, low water on spring tides is close to 06.00 and 18.00 and these algae would not be exposed to as much illumination as samples from South Wales were low tide is close to midday and illumination more intense. Therefore, the contribution that these algae may make to the local air will be regionally dependent on the timing of the tide. In the UK, the seawater and consequently the atmosphere may receive greater inputs from Laminaria in south west England and South Wales which have low water springs around midday compared to North Wales and the Southern North Sea (e.g. Lowestoft) where low water springs occur around 06.00 or 18.00 .

Sulphur containing compounds were produced in greater amounts by algae during dark conditions (see Figures 2, 3 and 5) suggesting that these compounds are the product of algal respiration or other process rather than photosynthesis. Dimethylsulphoniopropionate (DMSP) is often accumulated in 
high concentrations as an osmo-regulatory solute by many green macroalgae ${ }^{41}$ : It acts as a precursor of DMS and this production can be mediated by marine bacteria living in the algae during algae decomposition ${ }^{42}$. Aldehydes have been reported to be toxic compounds produced by algae as a mechanism of defence 43. Broadgate, et al. $2004{ }^{44}$ observed that alkane emissions from macroalgae were generally greater in the dark and when photosynthesis was inhibited. They proposed that alkanes were produced in response to the stress imposed by the inhibition of photosynthesis at the time of day when light is normally abundant. Our findings are consistent with this view (Figure 5). The production of NMHC was present under both light and dark conditions suggesting that the production of VOCs was independent of photosynthesis and may involve other metabolic processes such as respiration or osmo-regulation.

The production of total VOCs was dominated by green algae. However, the abundance and extent of green algae is greater during spring than summer 45 , and unlike brown algae, they are not the dominant group throughout the year. When total algal biomass is considered, brown algae are probably the main contributors of VOCs to Northern European coastal zones. Investigation into the source of VOCs using PLS (Partial Least Squares) modelling to explain the variance in Menai Strait seawater, signatures were developed using individual contributions from green, brown and red macroalgae ${ }^{46}$. The results demonstrated that brown algae were a better predictor of the variance of the VOCs in seawater than the other macroalgae, principally due to their abundance in the intertidal zone. It is also important to consider that even though all visible organisms were removed from the algal surface, is not possible to assume that all the volatiles found were produced by the algae themselves. Some algae will covered by marine bacteria which may contribute to the production although these are unlikely to be greater than the algal production itself based on biomass alone.

Our findings showed that the concentrations of iodomethane and all the iodinated compounds detected tended to increase under desiccation. However, chloroform and the remainder of the chlorinated compounds decreased, except in Ascophyllum nodosum whose production of iodinated compounds appeared to be independent of desiccation time (see Figure 4a). These results contrast with the findings of Nightingale, et al. $1995{ }^{27}$ who found enhancements in the production of chloroform, iodomethane and other halogenated compounds in Ascophyllum nodosum. Laminaria digitata produced much greater amounts of iodinated compounds, suggesting that for this alga desiccation stimulates the production of these compounds. The findings of Palmer, et al. $2005{ }^{47}$ investigating the different oxidative stress on Laminaria digitata suggested that this alga releases a burst of volatile iodinated compounds and even greater amount of molecular iodine which would not be detected by the methodology employed here. In general, VOCs (Figure 4h) tended to increase with increasing desiccation; this indicates that VOC production by macroalgae is promoted by oxidative stress due to partial desiccation after being exposed to the air. This production changed according to the habitat range in the intertidal profile with lower production rates for high water algae (desiccation tolerant) and higher for low tide algae that are less tolerant to desiccation.

To place these data in context, microalgae were also shown to produce halogenated, sulphur and oxygen containing VOCs which varied throughout their growth ${ }^{34}$. This microalgal signature only dominated the seawater profile for two months of the year covering the bloom period of these species ${ }^{46}$. Contributions from the sediments ${ }^{31}$ increased following the senescence of the microalgae ${ }^{46}$. In contrast, the macroalgae contributed throughout the year and were the principal identifiable source of VOCs to the coastal water in this uncontaminated area. Many of these compounds readily cross the sea - atmosphere interface and contribute to the local atmospheric chemical system. Measurements made in the air $10 \mathrm{~cm}$ above the seawater ${ }^{46}$ indicated fluxes of chlorinated compounds were greatest followed by iodinated and then brominated halocarbons. The macroalgae are contributing VOCs to the seawater which in turn outgas to the atmosphere; these emissions may contribute significantly to coastal air quality even in the absence of industrial / anthropogenic sources.

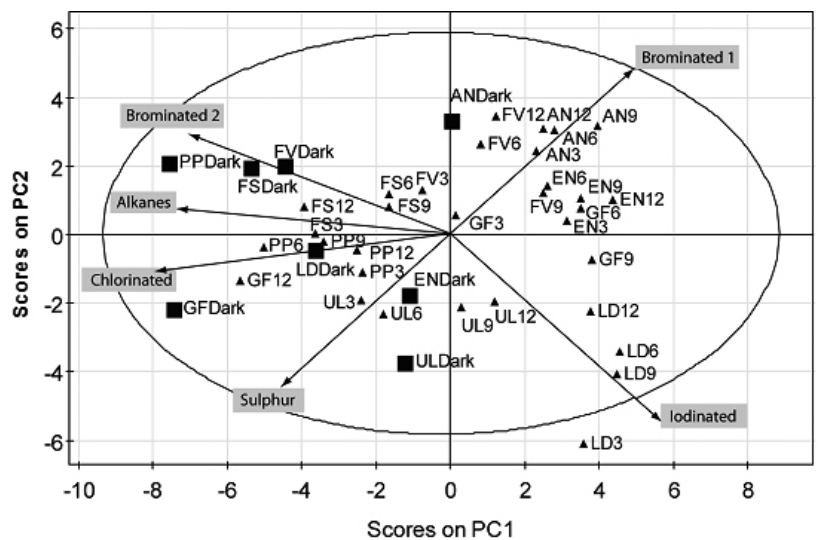

Fig. 5. Loadings and Scores plots after PCA of the VOC flux data after illumination. $\mathrm{PC} 1$ explained $32 \%$ of the variance and $\mathrm{PC} 217 \%$. The squares indicate the position in this 2D space of the algae kept in the dark. The triangles indicate the position of the illuminated samples for 3, 6, 9 or 12 hours. The species are AN: Ascophyllum nodosum, FV: Fucus vesiculosus, FS: Fucus serratus, LD: Laminaria digitata, UL: Ulva lactuca, EN: Enteromorpha sp, PP: Palmaria palmata and GF: Griffithsia flosculosa. The mean projection of the VOCs (loadings) can be seen by the vectors and shaded boxes. Brominated 1 contained bromoform and 2,3 dibromopropene while Brominated 2 contained the other bromine compounds.

\section{CONCLUSIONS}

Marine macroalgae can produce a broad variety of VOCs. Total production of VOCs showed that the production of compounds under illumination and darkness were not considerably different suggesting that the production of VOCs is present during algae photosynthesis as well in others metabolic processes such as respiration.

Desiccation play an important role in the production of VOCs, finding showed VOCs tended to increase after desiccation indicating that VOCs production by macroalgae are promoted by desiccation after being exposed for certain period of time; the production had an increment according to the distribution in the intertidal profile, having lower production for high water algae and higher for low tide algae.

Solid phase microextraction coupled to GC-MS showed to be a good technique to evaluate a broad amount of VOCs during this study.

\section{ACKNOWLEDGMENTS}

Claudio Bravo-Linares would like to acknowledge the support of his Scholarship funded by the European Community through the ALban programme code E03D00781CL.

\section{REFERENCES}

1. Gribble, G. W., Chemosphere 52, 289, (2003).

2. Gribble, G. J., Environ. Sci. Pollut. Res. 7, 37, (2000).

3. Gagosian, R. B.; Lee, C., Processes Controlling the distribution of biogenic organic compounds in seawater. Marine organic chemistry, evolution, composition, interactions and chemistry of organic mater in seawater. Duursma, E. K.; Dawson, R. 1981; pp. 91-107.

4. Laturnus, F., Mar. Chem. 55, 359, (1996)

5. Collen, J.; Pedersen, M., Eur. J. Phycol. 31, 265, (1996).

6. Potin, P., Oxidative Burst and Related Responses in Biotic Interactions of Algae. Algal Chemical Ecology. 2008; pp. 245-271.

7. Young, D. N.; McConnell, O. J.; Fenical, W., Phytochemistry 20, 2335, (1981).

8. Neidleman, S. L.; Geigert, J., Endeavour 11, 5, (1987).

9. Laturnus, F., Environ. Sci. Pollut. R. 8, 103, (2001).

10. Baker, J. M.; Reeves, C. E.; Nightingale, P. D.; Penkett, S. A.; Gibb, S. W.; Hatton, A. D., Mar. Chem. 64, 267, (1999).

11. Carpenter, L. J.; Liss, P. S., J. Geophys. Res.-Atmos. 105, 20539, (2000).

12. Giese, B.; Laturnus, F.; Adams, F. C.; Wiencke, C., Environ. Sci. Technol. 33, 2432, (1999). 
13. Goodwin, K. D.; North, W. J.; Lidstrom, M. E., Limnol. Oceanogr. 42, 1725, (1997).

14. Abrahamsson, K.; Ekdahl, A.; Collen, J.; Pedersen, M., Limnol. Oceanogr. 40, 1321, (1995).

15. Scarratt, M. G.; Moore, R. M., Mar. Chem. 59, 311, (1998).

16. van Pee, K. H., Archives of Microbiology 175, 250, (2001).

17. Manley, S. L.; Barbero, P. E., Limnol. Oceanogr. 46, 1392, (2001).

18. Almeida, M. G.; Humanes, M.; Melo, R.; Silva, J. A.; da Silva, J.; Wever, R., Phytochemistry 54, 5, (2000).

19. Colin, C.; Leblanc, C.; Wagner, E.; Delage, L.; Leize-Wagner, E.; Van Dorsselaer, A.; Kloareg, B.; Potin, P., J. Biol. Chem. 278, 23545, (2003).

20. Leblanc, C.; Colin, C.; Cosse, A.; Delage, L.; La Barre, S.; Morin, P.; Fievet, B.; Voiseux, C.; Ambroise, Y.; Verhaeghe, E.; Amouroux, D.; Donard, O.; Tessier, E.; Potin, P., Biochimie 88, 1773, (2006).

21. Moore, R. M., Mar. Chem. 101, 213, (2006).

22. Ohsawa, N.; Tsujita, M.; Morikawa, S.; Itoh, N., Biosci. Biotechnol. Biochem. 65, 2397, (2001).

23. Wever, R.; Tromp, M. G. M.; Krenn, B. E.; Marjani, A.; Vantol, M., Enviro. Sci. Technol. 25, 446, (1991).

24. Laturnus, F.; Giese, B.; Wiencke, C.; Adams, F. C., Fresen. J. Anal. Chem. 368, 297, (2000).

25. Carpenter, L. J.; Malin, G.; Liss, P. S.; Kupper, F. C., Glob. Biogeochem. Cycle 14, 1191, (2000).

26. Ekdahl, A.; Pedersen, M.; Abrahamsson, K., Mar. Chem. 63, 1, (1998).

27. Nightingale, P. D.; Malin, G.; Liss, P. S., Limnol. Oceanogr. 40, 680, (1995).

28. Jia, C.; Batterman, S.; Godwin, C., Atmos. Environ. 42, 2083, (2008).

29. Pirjola, L., J. Aerosol. Sci. 30, 355, (1999).

30. Steinbrecher, R.; Koppmann, R., Chem. Unserer Zeit 41, 286, (2007).

31. Bravo-Linares, C. M.; Mudge, S. M., J. Environ. Monitor. 9, 411, (2007).

32. Bravo-Linares, C. M.; Mudge, S. M.; Loyola, R. H., Mar. Pollut. Bull. 54, 1742, (2007).
33. Bravo-Linares, C. M.; Mudge, S. M., Volatiles Organic Compounds (VOCs) analysis in water, sediments and soils and their application in environmental forensics. Methods in Environmental Forensics ed.; Mudge, S. M., CRC Press: Boca Raton, 2008; pp. 173-196.

34. Bravo-Linares, C. M. Temporal variation, occurrence and factors controlling the production and concentrations of VOCs in the marine environment. Ph.D., Bangor University, 2007.

35. Collen, J.; Ekdahl, A.; Abrahamsson, K.; Pedersen, M., Phytochemistry 36, 1197, (1994).

36. Marshall, R. A.; Hamilton, J. T. G.; Dring, M. J.; Harper, D. B., LimnoL. Oceanogr. 45, 516, (2000).

37. Scarratt, M. G.; Moore, R. M., Limnol. Oceanogr. 44, 703, (1999).

38. Kupper, F. C.; Carpenter, L. J.; McFiggans, G. B.; Palmer, C. J.; Waite, T. J.; Boneberg, E. M.; Woitsch, S.; Weiller, M.; Abela, R.; Grolimund, D.; Potin, P.; Butler, A.; Luther, G. W.; Kroneck, P. M. H.; Meyer-Klaucke, W.; Feiters, M. C., Proc. Natl. Acad. Sci. U. S. A. 105, 6954, (2008).

39. Klick, S., Mar. Chem. 42, 211, (1993).

40. Giese, B.; Laturnus, F.; Adams, F. C.; Wiencke, C., Environ. Sci. Technol. 33, 2432, (1999).

41. Van Alstyne, K. L.; Wolfe, G. V.; Freidenburg, T. L.; Neill, A.; Hicken, C., Mar. Ecol.-Prog. Ser. 213, 53, (2001).

42. Castaldelli, G.; Welsh, D. T.; Flachi, G.; Zucchini, G.; Colombo, G.; Rossi, R.; Fano, E. A., Aquat. Bot. 75, 111, (2003).

43. Paul, V. J.; Puglisi, M. P., Nat. Prod. Rep. 21, 189, (2004).

44. Broadgate, W. J.; Malin, G.; Kupper, F. C.; Thompson, A.; Liss, P. S., Mar. Chem. 88, 61, (2004).

45. Taylor, R.; Fletcher, R. L.; Raven, J. A., Bot. Marina 44, 327, (2001).

46. Bravo-Linares, C. M.; Mudge, S. M., J. Environ. Monit. 11, 628, (2009).

47. Palmer, C. J.; Anders, T. L.; Carpenter, L. J.; Kupper, F. C.; McFiggans, G. B., Environ. Chem. 2, 282, (2005). 